\title{
Canning and Denmark in 1807
}

GOME of the questions connected with the bombardment of Copen. $N$ hagen and the capture of the Danish fleet in SeptemberOctober 1807, have never yet been explained, and probably never will bo completely cleared up; but new light is, I think, thrown on them from some of the records, which, by the kind permission of the Foreign Office and of the Admiralty authorities, I have been able to examine at the Record Office. ${ }^{1}$ The recent publication in extenso of the secret articles of the treaties of Tilsit ( $7 \mathrm{July} \mathrm{1807)}$ revealed the text of the agreement whereby the tsar Alesander consented to make common cause with Napoleon against Great Britain, if the latter did not before 1 Nov. 1807 mitigate the severity of her first orders in council and agree to restore to France her maritime conquests effected since the year 1805. In case of England's nonacceptance of these terms by 1 Dec. 1807 the tro emperors agreed to sumnion the three courts of Copenhagen, Stochholm, and Lisbon to close their ports to the English, and declare war against England. That one of the three courts which refuses shall be treated as an enemy; and in the case of Sweden refusing Denmark shall be compelled to declare war against her.

Hor the news of this important proposal reached the English government the despatches of our foreign office, very naturally, do not say; but they contain the following significant statement of our umbassador to Russia, Lord Leveson Gower, dated Memel, $15 \mathrm{July}$ 1807 :-

It was strongly reported at Königsberg among the French that Bernadotte had received orders to march against Holstein, with the view of forcing the court of Copenhagen to shut the passage of the Sound against the English.

Our envoy further reports Napoleon's determination to expel the Swedes from their Pomeranian possessions, and to have all Russian and Prussian ports closed against English ships. Bat, as information reached Canning on 21 July, it may be presumed to have been anterior to this. The French, following a bint in

'The chief account of the Copenhagen affair is that given in the drnual Register for 1807, which publishes the proclametions, terms of the cepitalation, and some fer interesting documents besides. The Arnual Rcgister for 1808 also contains a full digest of the debates on the king's speech of Januery 1808. They torned mainly on the Copenhagen affair, bat revealed nothing not known before. 
Fouché's 'Memoirs,' have suspected Talleyrand of having played the informer; and the disgust which Tallegrand felt for Napoleon at Tilsit ${ }^{2}$ lends some colour to the supposition that there, as at Vienna in 1805 , he had secretly done his best to prevent the ruin of the old monarchies.

Whatever may have been the channel, or channels, of com. munication for the important news sent to Canning, there can be no doubt of its correctness. Napoleon's correspondence yields ample proof of his determination to compel Denmark to take sides against England and Sweden. Thus on 2 Ang. 1807 he wrote to Bernadotte, 'If England refases to accept the Russian mediation, Denmark must declare war against her, or I must declare war against Denmark. In the latter case your daty will be to seize the whole of the mainland of Denmark.' In naval operations Englated acted with none of the supineness which in her military affairs had-recently aroused the wrath of the czar. Admiral Gambier, with twenty-four British ships of war, appeared in the Sound on 3 Aug.; and subsequent additions from England and from the force which was already doing duty at Stralsund and Rügen brought up the total strength of his fleet to eighty-eight ships (3 Sept.), besides twenty others which were cruising off Rügen or in the Cattegat. ${ }^{3}$ The power of this fleet serves to show the importance attached by our government to an immediate and peaceful attainment of the aims proposed.

These aims are set forth in the following instructions, dated

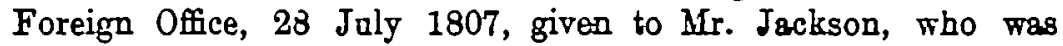
accredited as special envoy to the Danish prince royal :-

In consequence of intelligence which has been received here, through various channels, ${ }^{4}$ of the designs of Bonsparte to occupy the territory and ports of Holstein, for the purpose of shutting out Great Britain from all communication with the continent, and ultimately to arail himself of the Danish marine as an instrument of active bostility against this country, it has become necessary that the most prompt and decisive explanation should immediately be entered into with the court of Denmark.

The enroy is then charged to express

his majesty's just determination to obtain for himself that satisfaction and security which the designs of the enemy and the situation of Denmark impose on his majesty the necessity of requiring. The forward state of equipment of the Danish fleet would alone have entitled his

- Les engagements qu'il avait fait rompre at ceux qu'il avait fait prendro l'avaiont enivrt. On the other hand Mr. FJffe's suggestion (History of Madern Europe, rol. i. p. 850, note) that the information came from one of the Anglophil Bassian diplomatists has moch to recommend it.

- Captain Mahan (ii. 276), in his brief bat very tomperate treatment of this subject, somewhat anderrates the numbers of the flect. It ras perhaps the most powerful tleet which had ever left our shores.

- The plural would seem to imply that there was not, as has been generally sssumed, ang one sathoritative chnonel of communication. 
majesty to require such satisfrction. That equipment could be made in no other contemplation than that of eventual hostility against Great Britain. The tone which Denmark has assumed in the discussions with this country relating to that mitigated measure of reprisal which his majesty bad been driven to the necessity of adopting in consequence of the French decree of blockade, compared with the forbearance which she appears to have shown in respect to any remonstrance on the subject of the French decree itself, must naturally bare excited a suspicion in his majesty's mind ... of the ill disposition of the court of Denmark towards the country. ... It is only by receiving an adequate pledge and security for the adherence of Denmark to whaterer engagements she may enter into that his majesty can consider himself as haring obtained such satisfaction as it is his duty to demand.

From this despatch it is obvious that the irritation between England and Denmark on the subject of neutral commerce must be considered as indirectly contribating torards the unhappy events of September 1807. When it became a question for Denmark to decide at eight days' notice for or against an alliance with the power which had crippled her nary in 1801, and was now cramping her commerce, she naturally decided against it. She had almost openly expressed her sympathy with France at the commencement of the war of 1805 ; and there ras every ground for beliering that, unless strong pressure was ased, she would now side with the power which could wrest from her her German lands.

As to the statement made in the instructions to Mr. Jackson that the Danish navy was in a forward state of equipment for sea, it cau be shown from our own archives that our government was completely misinformed. In the admiralty records of Admiral Grubier's expedition there is a report drawn up, at the instance of the admiral himself, by Captain Francis Beauman. This officer reported that be visited the dockyard, ships, sc., at Copenbagen on 25 July 1807, and found 'in a state of ordinary 18 sail of the line, 11 frigates, 10 sloops, 4 floating batteries, and sereral small gunboats.' All were in excellent repair and ' compleatest order.'

I am of opinion [he continues] the whole of the Danish fleet might with the greatest ease, provided it had seamen, be at sea in air meeks from the commencement of their equipment. . . . I may venture to assert there is not at present the shadow of appearance for the equipment of a flect, as it is inpossible it could be hid from the eye of any noval officer.

That Admiral Gambier completely credited his officer's report is prored by the insertion of a clause in the terms of the capitulation of Copenhagen to the effect that the British forces were to eracuate Zealand within sir recks, or earlier if possible. That space of time was fixed, in all probability, on the ground of Captain Beanman's report; and the issue of erents proved the correctness of the captain's judgment. 
As Captain Beauman's examination was made on 25 Joly, it was impossible for the erroneous impressions of the British government to be removed until it was too late to recede, even if it had been desirous of so doing. Furthermore, the knowledge that the English government had been misled as to the condition of the Danish fleet must have prejudiced the court of Copenhagen against any offers of alliance in which the surrender of the fleet was urged as an indispensable preliminary. It is quite possible also that Admiral Gambiar and Lord Cathcart, after becoming convinced that the Danish fleet was ouly in its normal condition, must have felt additional repugnance at its seizure; and their desire to be quit of an inglorious and painful duty may partly account for their proposal of terms of capitulation, which contravened the larger and more statesmanlike views that Canning undoubtedly cherished.

Mr. Jackson was distinctly informed in his original instructions of $28 \mathrm{July}$ that the British government, being 'not unsware of the apparent harshness of the demand ' (for the surrender of the fleet in pledge), was ready to enter into any reasonable stipulations which the court of Denmark might suggest. These might be (1) a treaty of alliance and mutual defence, or (2) the fleet was to be receired as a 'sacred depnsit and with a solemn convention as to its restoration at the conclusion of the war.' In the first case it was proposed that the British government should sabsidise Denmark at the rate of 100,000 Dutch florins for 1,000 foot soldiers, and 120,000 Dutch florins for 1,000 horse-soldiers, which she should keep on active service; and a British fleet of 15 ships of the line and 6 frigates was to be offered for her defence.

As an alternative plan a projest of a secret treaty was to bo offered for-(a) the handing over of the Danish fleet as a 'sacred pledge' till the peace; (b) a sulssidy of $100,000 l$. for the service of the Danish fleet ; (c) relaxation of the blockade then imposed on Danish ports and rivers; (d) assistance to Denmark in case she should be attacked; (e) a defensive alliance was to be formed; $(f)$ this treaty was to be secret. In these original instructions it is evident that Denmark was to be offered fair and honourable terms, and that her alliance was strongly desired as a means of staying the course of French conquest, and of protecting our ally, Sweden, from pressure on the west. Obviously this was the only bope of keeping Sweden from the grasp of the trro mighty potentates who now disposed of the furtunes of Europe. Enough was known of their policy at Tilsit to show that Sweden was in great danger on the side of Russia. The British gorernment, therefore, was morally justified in bringing considerable pressure to bear upon Denmark, so as to prevent her falling into the power of the two emperors and thas assuring the ruin of Sweden by an invasion from Norway. True, the pressure which Canning proposed to exert on Denmark was painful 
and onerous; but he expressly asserted in the instructions that a demonstration of overwhelming force should be mule, with a riew to saring the honour of the Danish gorernment. It is clear, then, that the British government never contemplated the seizure of the Danish fleet, or eren its temporary appropriation in deposit, as the beginning and end of their policy. Oar ministers were desirous of saving from the wreck of the European system the maritime peoples of the north by adding Denmark as an important connecting link to the already existing alliance betreen Englend and Sweden. Only thus conld Napnleon's continental system be rendered inoperative. Only by an Anglo-Scandinarian alliance could the north of Europe be kept free from the oppressive yoke which lay upon its central and southern states.

Canning, however, in his second memorandum to Jackson neatralised the effect of his first instractions. This document, dated Foreign office, $29 \mathrm{Jaly}$, and marked 'Separate and most secret,' contrins the following statement:-

You will carefully bear in mind that the possession of the Danish fleet is the one main and indispensable object to which the whole of your negotiations is [sic] to be directed, and without which no other stipulatiou or concession can be considered as of ang value or importance. In the event, therefore, of the Danish gorernment even cousenting to enter into the treaty of alliance as proposed in the project with which you are furnished, it will be necessary that a secret article should be added to this treaty, by which the delivery of the Danish fleet must be stipulated to take place forthwith, and without waiting for the formality of the ratification of the treaty.

(Signed, G. Carviva.)

The space of eight days was to be granted to the Danish gorernment for consicleration; and after that time had elapsed the British fleet and forces were to consider the want of any result as proof of a refusal to treat, and were ' to proceed to act accordingly.' The sequel will show that first Mr. Jackson, and sabsequently Admiral Gambier and Lord Cathcart, appear to have regarded the proposals of aliiance as of secondary importance, and to hare acted as if the surrender of the fleet was alone essential.

Proceeding to Denmark, Jackson had un interriew first mith the Danish minister, Bernstorff, who, on Jacison's assertion that Bonaparte ras planning the seizure of the Danish fleet,

asserted with the most violent expressions and gestures that his majesty's gorernment was iu possession of no such information, that it was mere conjecture, that we were lightly and hastily misled by false reports and surmises, which I myself did not believe . . that I was forcing Denmark into a war.

In reply Jackson stated that he (Bernstorff) might be rell assured of the 'anthenticity of the adrices (sic) on which the present proceeding was grounded.' It seems, then, that the 
English envoy, at the outset of his difficult negotiations, committed the tactical error of placing the question of the fleet in the very forefront of all his communications, instead of naming it as an indispensable condition of an Anglo-Danish alliance: Canning regarded the delivery of the Danish fleet 'in deposit' as a necessary guarantee for such an alliance, as well as for the purpose of removing any motive for a French occupation of Denmark; but bis instructions were for an alliance in which the delivery of the fleet occurred as a second though all-important condition.

In reporting the interview which be had on 9 Ang. with the Danish prince royal at Kiel, Jackson seems to admit that he did not begin by inviting the prince to consider the alternative treaties of alliance, projects of whiçh had been drawn up by Canning. He appears to have gone straight to the most difficult and delicate part of all his negotiations. 'I declared to him that in the present state of the north of Europe the delivery of the Danish fleet into his majesty's hands had become a matter of indispensable necessity.' Jackson then stated the alternative lines of policy which were open to Denmark-either (1) alliance with England, the co-operation of naval and military proceedings, the guarantee of all the Danish possessions, and the certainty of aggrandisement to Denmark at the conclusion of a general peace; or (2) the immediate operations of a vast military and naval force upon a populous and commercial city. He stated his majesty's heartfelt desire that the prince should choose the former alternative.s

The prince replied that if Bonaparte invaded Holstein Denmark would then become the natoral ally of Great Britain. He also urged very strongly the cruelty and injustice of forcing Denmark from her system of neutrality. To this Jackson replied that he was instructed only to propose an immediate alliance, not one after Bonaparte had deprived Denmark of the greatest part of her means of action. The English envoy admitted that the alternative was distressing, but that if the Danish fleet were given up Bonaparte would be more likely to make a general peace.

The prince, however, was ' affected by the menace accompanying the terms, which rendered them the more offensive.' He returned no reply, but set off at once for Copenhagen, whither Jackson followed him; bat when our envoy requested a further interview with him he was informed that the prince had returned to Holstein and had left Bernstorfi with no powers to negotiate. Justly considering this as tantamount to a refusal of his demands, Jackson retired to the fleet. The British land forces were accordingly disembarked at Wibeck, between Elsinore and Copenhagen, on 16 Aug.; and on that same day a proclamation was issued by

s Jakson does not appenr to have named the terms of the second (seoret) treaty of alliance, set forth in his original instractions. 
Admiral Gambier and Lord Catheart, of which the most important statements are as follows :-

We ask deposit (of the Danish fleet). We have not looked to captare; so far from it, the most solemn pledge has been offered to your govern. ment, and is bereby renewed in the name and at the express command of the king, our master, that if our demand is amicably acceded to every ship belonging to Denmark shall, at the conclusion of a general peace, be restored to her in the same condition and state of equipment as when received under the protection of the British flag. . . . His majesty's sesmen and soldiers, when on shore, will treat Zealand, as long as your conduct to them permits it, on the footing of a province of the most friendly power in alliance with Great Britain, whose territory has the misfortune to be the theatre of war. . . . (Articles of food, fuel, \&.c., will be paid for, though requisitions must unaroidably be made.) . . . The government of his Danish majesty having hitherto refused to treat this matter in an amicable ray, part of the army has been disembarked, and the whole force has assumed a warlike attitude; bat it is, as yet, not too late for the voice of reason and moderation to be heard.

The Danish gorernment, horrerer, regarded the disembarkation as the commencement of hostilities, and issued a proclamation on 16 Aug. 'Hostilities haring commenced on the part of the English ... all English property is sequestrated.' Nevertheless on 1 Sept. 1807 Gambier and Cathcart renered their offer of an amicable settlement in a despatch sent to General Peinan, the governor of Copenhagen, asserting that the Danish fleet should be restored at the general peace in as good condition as it was when received in deposit. ' But,' continues the despatch, ' if this offer is rejected now it cannot be repeated. The captured property, public and private, must then belong to the captors; and the city, when taken, must share the fate of conquered places.' A temporising reply having been received, the bombardment commenced on 2 Sept.; and on 5 Sept. Gambier reports, "For the twat two days the conflagration has been very considerable, and at this moment rages with great violence.' On the evening of that day a Danish officer came with a flag of truce; and negotiations began, which ended in the articles of capitalation being signed on 7 Sept. $^{6}$ The English forces were to occupy the citadel and dockyard; the ships and stores were to be delivered up ${ }^{7}$ and (article v.) within six weeks, or earlier if possible, the English forces rere to evacuate Zealand.

Admiral Gambier in a despatch of 15 Oct. reports 'the scrupalous exactness that the Danes have observed in adhering to the terms of the capitalation.' He also reports, after an examinstion

- The articles heving been pablished (ree Arr. Reg. 1807, p. 695) it is onnecessary to give them in fall here. At the head of the Engligh signatories comes the name of Bir Arthar Tellesles.

T There mas no mention made of restitution. The ships given up comprised one of 96 gans, two 84's, twelve 74's, fifteen trigates, six brigs, twenty-five gunbonts Most of them were sold in or after 1814 . 
of the cosst of Zealand, that it would be difficult, if not impossible, to hold Zealand against the hostility of France, unless with a larger force than was then at his and Lord Cathcart's disposal. This opinion, coinciding with the commanders' views as to the chief aim of the expedition, led them to press on the equipment of the Danish fleet, so as to take it away at the earliest time possible. ${ }^{8}$ The Danish ships pere got ready for sea in the required time, and Gambier's great fleet reached Yarmouth Roads on 29 Oct. In one of his last despatches (20 Oct.) he adverts to the offer, made by Mr. Pierrepoint to the Swedish king, that the British land forces should assist in the defence of Sweden. The offer was refused by that monarch. On the surrender of Copenhagen Mr. Jackson immediately applied to General Peiman for a passport to return to England through Holstein, for the purpose of having an interview with the prince royal, and thus bringing about the 're-establishment of perfect harmony and good anderstanding between our two countries. This WR. the original object of my mission; nobody regrets more than I do that it did not succoed in the first instance.' Mr. Jackson's effort was as unarailing as the previous one. That Canning regarded this abrupt issue of his policy as unsatisfactory and unfortnnate is prored by two documents in ' Foreign Correspondence,' Denmurk, vol. 197. The first is undated, bat is pencilled on the back, 'For Mr. Pierrepoint, about Oct. 1807.' The preliminary article is as follows :-

The capitulntion to be executed according to its true sense and meaning, as understood by the officers who settled it. But in the event of a refusal on the part of the court of Denmark to execute any article according to what is conceived to be its true sense, the military possession of Zealand to be continued antil such sense shall have been clearly ascertained and acted upon. And, at all events, it is understood that this military possession is to be continued by mutual consent until the conclusion of the negotiations for peace between the two powers.

There follows a draft of a 'Proposed Basis of Negotiation,' in which the alternative of neatrality or alliance with England is to be offered to Denmark; and the offer of the restitution of the Danish fleet within three years of a general peace is again made. Canning's disappointment and chagrin at the terms of capitolation of 7 Sept., especially at the fixing of so short a term as sir weeks for the evacuation of Zealand, are eren more decisively asserted in a further memorandum, printed below. It bears no date, but there is pencilled on the back 'About Sept. 1807.' No signsture is appended, bat the.writing is unquestionably that of Canning.

- In the heated dobates on the king's speech in Jenusery-Fobrang 1808 the difficnity or impossibility of bolding Zoaland wes arged by minirters as the chief excuse for the speedy evecuation, Inord Castlereagh stating that bad our war ships been dirtribated so as to gased the coest they rould have been fire miles apart. Canning's despatches, horever, prove his extreme annogance at article $\nabla_{\text {n }}$ and his desire to orede it if possible. 
It is evident from the tenor of Lord Catheart's Dispatches, and from his description of the State of Copenhagen, that the insertion of the Article of the Capitulation, by which the Island of Zealand is stipulated to be eracuated in six weels, was not at all necessary in order to accelerate or enforce the Reduction of the City. Had the surrender of the Fortress, the Navy, and the Arsenal been demanded with only the common Stipulations dictated by Humanity, and calculated as the Basis of its future Government, and unconditionally with regard to the Term of its Occupation, there cannot exist a Doubt that the Demand must have been complied with. The Proposels made to the Danish General by the Joint Commanders in Chief on September 1, with the menace (in case of Refusal) to trest the City as other conquered Places, place this matter beyond Question. For how could the Danish Commander in Chief flatter himself with the Hope of receiving, after a successful and destructire Siege, better Terms than those which he had refused before the Bombardment? It follows, therefore, incontestably that his Lordship, in stipulating the eracuation of Zealand, pursued only the Idea imposed upon him by his original Instructions, of obtaining possession of the Danish Fleet and Arsenals, and added voluntarily erery Stipalation which could serve to tranquillize the Ferment of its Inhabitants, and console them as to their future Destiny, without adverting to the entire new Face given to the whole Question ly the existing and declared War on the part of the Crown of Denmark against Great Britain.

In this view of the subject, the correctness of which can herdly be disputed, Great Britain cannot fairly be accused in the face of Europe of having obtained Possession of Advantages by the Stipulation of Conditions which she afterwards refuses to fulfil, because the unconditional attainment of her Object was most completely in Ler Power. The Accusation of Breach of Faith is therefore completely done away; and the Question rests once more upon the Erpediency and Utility of the continued Occupation of Zealand, with the sole views which have animated His Majesty's Government in the Equipment and in the Issue of the Expedition.

What are these riews? Not those of Hostility against Denmark, not those of violating the Integrity of the Danish Monarchy, or of dismembering his Dominions, but of raising a Barrier against the System of Subversion and Revolution which has nearly changed the Face of Earope, and of arrest. ing its Progress there, where Great Britain can interfere with an irresistible effect. The Possession of the Danish Fleet, with or without the Consent of the Crown of Denmark, although it removes a part of the Instraments which might have been turned against the Safety of Great Britain or of the States North of the Baltic, is in itself not only not safficient to arert the great and principal Eril, but is calculated, unless accompanied by other Ilessures of Occupation, to accelerate its Arrival and its complete Success. For it deprives Denmark of the power of stopping the Adrance of the French, where she possessed, with her Nary, the ample Means of doing so. If she' rere also animated with the Inclinstion to defend her Independence in the Islands against France, it is hardly too much to say that the solitary individual Act of seizing her Fleet, and thus depriving her of the Power, becomes an Act of great Injustice.

On the evacuation of Zciland by the English Troops, it cannot be 
doubted that it will be occapied by the whole Danish Army, and most probably by the French Armies: that the Mlonarchy of Sweden, menaced by France on one side and invaded by Russia on the other, will either be subverted and compelled to join the System of Measures against England, or will be intimidated or seduced into them.

As a Friend or as an Enemy (sic), the Eracuation of Zealand seems to ensure the inevitable Loss of Sweden to Englend; and the most probable of all Events is that, in the ensuing spring, His Majesty's Government will have to equip a netw Expedition against Copenhagen and Zealand, protected by a Danish, and probably by a French, Army, and covered by an united Russian and Swedish Fleet. Everything is to be hoped from the Genius of Great Eritain and from the Valour of her Subjects : bat it will hardly be too much, after the recent experience, to say that ahe will not attain her Object without prodigions Exertions, and that her Success is at tbe least doubtful in the Recorery of an Object which she has now in her complete Possession.

Omitting any reference to the casuistry by which Canning persusdes himself that the obnoxious article of the capitulation may be set aside, it may suffice to observe the extreme importance which he attaches to a continuance of our occupation of Zealand as a means of compelling Denmark to join in the formation of an Anglo-Scandinavian alliance. It seems hardly to hare occurred to him at the outset that Denmark wonld repel the proffered alliance when urged by a fleet more than twice as large as that which had silenced their armed halks six years before; still less, perhaps, did he, or the commanders of the present expedition, imagine that after the capture of her fleet Denmark would persist in hostilities. It was in vain, however, that Canning sought for an opportunity of escaping from article $\nabla$. The Danes gave no loophole of escape, and persistently refused all attempts at pacification. The English, after doing their worst, had now tied their own hands by the terms of the capitulation; and the fatare seemed to open to Denmark the prospect of revenge if she joined the attacks of the two emperors on Sweden. She gained her revenge, but at the cost of future disasters.

The resolve of the Danish government showg itself in its refusel to listen to Canning's last efforts at conciliation. Instructions were drawn up on 27 Sept. for Mr. Merry, who was to proceed at once to Copenhagen.9 Alluding to the refusal of the Danes to allow Mrr. Jackson even to land at Niehborg for the parpose of an interview, a hope is expressed that this was 'due to temporary irritation,' and was not 'a determined purpose to remain at war with his majesty.' Mr. Merry is informed that the capitulation had been signed with the belief that the cessation of hostilitieg at Copenhagen was equivalent to ' $a$ termination of the war.' He was to point out that unlegs the Danish declaration of war was withdrawn the British forces would

1 For an account of Mr. Merry's mission see Mr. S. Laco-Poole's Lifo of Slratford Canriro, i $80-6$ (1888). 
not be remored far from Zealand, lest Streden should be left open to attack; and the reoccupation of Zealand ras to be hinted at as a last though most painful alternatire. These orertures could nerer even be proposed. The Dauish anthorities and the Russian ambassedor at Copenhagen threr difficnlties in Mierry's way. Hostilities were resumed by the Danes at the expiration of the armistice (23 Oct.), and did not cease until the treaty of Kiel (Jan. 181t).

A rerien of the evidence afforded by the documents of our foreign office seems to warrant the following conclusions :-

1. There is no documentary proof that Canning's information as to Napoleon's designs ras based on any one definite and authoritative statement; whereas the nse of the phrases 'channels of communication ' and ' authenticity of the advices' seems to point to tro or more unofficial, or semi-ofticial, reports.

2. The British government ras certainly misirformed as to the state of the Danish fleet ; but Captain Beauman's correcting report arrived too late to effect any change of policy, though it may have influenced the terms of the capitulation of 7 Sept.

3. Canning's original instructions to Jackson laid most stress on the proposal to the Danish gorernment of tro alternative treaties of alliance, in each of which the temporary transference of the Danish fleet was an essential condition.

4. These instructions were somerthat modified by the separate and secret arowal that the possession of the Danish fleet was ' the one main indispensable object ' of Jackson's mission.

5. Jackson seems to have imperilled the altimate success of his very difficult mission, and to have needlessly irritated Count Bernstorff and the Danish prince royal, by demanding first and foremost the sarrender of their fleet, while the offer of alliance was relegated to a secondary place.

6. The British commanders, by limiting their occupation of Zealand to the space of six weeks from 7 Sept., acted as though the capture of the fleet was the sole object of the expedition. They were also of opinion that Zealand could not be held except by a larger force than they then possessed. In any case, by imposing on thenselves a speedy evacuation of Zealand, they exceeded their powers, and rendered nugatory the success of the expedition.

7. Canning thereupon endearoured, though fruitlessly, to harc the occupation of Zealand prolonged, so as to realise the final aim of his policy, the formation of an Anglo-Scandinavian league.

8. His final efforts were foiled $(a)$ by the persistent refusal of the Danish court even to consider his proposals; (b) by the refusal of Gustarus IV to accept English military aid, whereby Sweden might have been secured against an imminent attack from the side of Denmark and Norway. 